\title{
Factors influencing variation of bulk milk antibiotic residue occurrence, somatic cell count, and total bacterial count in dairy sheep flocks
}

\author{
C. Gonzalo, ${ }^{* 1}$ J. A. Carriedo, ${ }^{*}$ M. C. García-Jimeno,† M. Pérez-Bilbao,† and L. F. de la Fuente* \\ *Departamento de Producción Animal, Facultad de Veterinaria, Universidad de León, 24071-León, Spain \\ †Consorcio de Promoción del Ovino, Carretera Zamora-Palencia, km 49, 49630-Villalpando, Zamora, Spain
}

\begin{abstract}
To study the variations of bulk tank milk variables in dairy ewe flocks and to identify the main target practices and flock groups to improve milk quality and safety, a total of 71,228 records of antibiotic residue (AR) and milk yield and 68,781 records of somatic cell count (SCC) and total bacterial count (TBC) were obtained over 5 yr from the same 209 dairy ewe flocks of the Assaf breed belonging to the Consortium for Ovine Promotion of Castilla-León (Spain). Based on a logistic regression model, year, month, semester, SCC, TBC, dry therapy, and milk yield significantly contributed to AR variation. High SCC was associated with increased AR violations. When antibiotic dry therapy was implemented, AR occurrence was higher than when this practice was not used. A polynomial monthly distribution throughout the year was observed for AR occurrence; the highest values were in autumn, coinciding with low milk yields per flock. Yearly occurrences drastically diminished from 2004 (1.36\%) to 2008 $(0.30 \%)$, probably as a result of effective educational programs. The mixed-model ANOVA of factors influencing variation in SCC and TBC indicated that year, month, AR, dry therapy group, milking type, and year interactions were significant variation factors for SCC and TBC; mathematical model accounted for 74.1 and $35.4 \%$ of total variance for each variable, respectively. Differences in management and hygiene practice caused significant SCC and TBC variations among flocks and within flocks throughout the 5-yr study. Over time, continuously dry treated flocks showed lower logSCC (5.80) and $\log \mathrm{TBC}(4.92)$ than untreated (6.10 and 5.18 , respectively) or discontinuously dry treated (6.01 and 5.05, respectively) flocks. Continuously dry treated flocks had lower AR occurrences than did discontinuously dry treated flocks. As a whole, AR occurrence and SCC and TBC bulk tank milk variables can be
\end{abstract}

Received October 20, 2009.

Accepted December 26, 2009.

${ }^{1}$ Corresponding author: c.gonzalo@unileon.es used for monitoring mammary health and milk hygiene and safety in dairy sheep throughout time.

Key words: antibiotic residue, somatic cell count, bacterial count, dairy sheep

\section{INTRODUCTION}

Antibiotic residue (AR) occurrence, SCC, and total bacterial count (TBC) of bulk tank milk are important to the farmers, cheese manufacturers, and consumers because they are major factors in determining safety and hygienic quality of the final product. Bulk tank parameters have been the target of different legal limits or payment-by-quality schemes proposed by different countries or regions, with obvious repercussion on the marketing of sheep milk. Thus, the European Union establishes both the maximum residue limits of specified veterinary residues (Council Regulation EEC 2377/1990 and subsequent amendments; European Union, 1990) and the limits for TBC (Council Regulation EEC 853/2004; European Union, 2004) in ovine milk, although the European Union has yet to regulate SCC values in ewe milk used for dairy products sold in its region. Castilla-León has about 1.5 million milking ewes and it is the first-largest region in Spain in ewe milk production. The study of AR occurrence, SCC, and TBC variations in milk must be emphasized in the main dairy sheep regions because the production of dairy products starts with raw milk.

Increasing awareness of public health and food safety issues in recent years has led to a greater interest in milk quality. Antibiotics residues are a result of treating dairy sheep with antibiotics and not withholding milk. The treatment of mastitis is probably the most common reason for an increased risk of AR occurrence in dairy farms (Allison, 1985), and a relationship between $\mathrm{AR}$ violations and SCC or level of subclinical mastitis has been evidenced in dairy cattle herds (Ruegg and Tabone, 2000; van Schaik et al., 2002). However, little attention has been paid to AR violations in dairy sheep. Yamaki et al. (2004) evidenced a seasonal effect of AR occurrence in raw and heated ewe milk in the Castilla-La Mancha region (Spain). Nevertheless, no 
known studies have empirically investigated the effect of variation factors, such as mastitis, antibiotic therapy, milking type, or milk production, on AR occurrence under field conditions in this species. The identification of risk factors to discriminate between flocks or practices that are at higher risk of AR violations would allow cost-effective targeting of regulatory, educational, and consultative resources in dairy sheep, in a similar way to dairy cattle (Ruegg and Tabone, 2000).

Bulk tank SCC and TBC are principal tools used by technicians and farmers to evaluate udder health as well as the efficiency of production processes and cleaning and sanitation practices. For these variables, the effects of several factors of variation have been recently studied in dairy ewe flocks by Gonzalo et al. (2005, 2006), who also evidenced a significant relationship between both variables. Nevertheless, the association between SCC and AR has not been studied in dairy sheep, and little attention has been paid to relationship between TBC and AR occurrence (Yamaki et al., 2004). In dairy sheep, high SCC levels have been shown to be related to IMI, milk yield losses, and lower quality of dairy products (Marco, 1994; Gonzalo et al., 2002; RaynalLjutovac et al., 2007), so preventive mastitis practices, such as antibiotic dry therapy, are frequently used in this species to improve the mammary health and milk yield and quality (Gonzalo et al., 2004b, 2005). In this regard, an attempt should be made to identify and interpret the variation of SCC, TBC, and AR occurrence from an integrated point of view because these variables reflect overall quality of management.

On the other hand, all the above-mentioned studies in dairy sheep were conducted over 1 yr; no known studies examine the variation of these variables over the course of several years. Because of the low occurrence of AR violations, long-term studies are the most suitable for AR occurrence investigation. Over time, observational studies could also allow an optimal knowledge of the effect of some health practices (e.g., dry therapy) or environmental factors (e.g., year) on hygienic variables of bulk tank milk, as well as of interactions between year and other factors of variation. Wider knowledge of AR occurrence, SCC, and TBC variations would enable decisions to be made on improving milk safety and quality, farm management practices, and flock mammary health.

We hypothesized that the study of AR occurrence, SCC, and TBC bulk tank milk variables would be of interest for monitoring the variations in flock mammary health and safety throughout the years. To test this hypothesis, the present study was conducted over 5 yr in 209 Assaf dairy flocks in the Castilla-León region. The objectives of this study were 1) to analyze the main sources of variation in AR occurrence as well as its relationship with SCC and TBC, and 2) to investigate the influence of the year effect and its interactions with other factors of interest, such as flock, milking type, and antibiotic dry therapy.

\section{MATERIALS AND METHODS}

A total of 71,228 records of AR and milk yield and 68,781 records of SCC and TBC variables of bulk tank milk were obtained over $5 \mathrm{yr}$ from the same 209 dairy ewe flocks of Assaf breed belonging to the Consortium for Ovine Promotion (CPO) of Castilla-León. All CPO flocks were enrolled in the analysis service of the Dairy Interprofessional Laboratory of Castilla-León. Bulk tank milk samples were collected from the flocks after milk homogenization, preserved with acidiol (3 $\mu \mathrm{L} / \mathrm{mL}$ ), and kept at $4^{\circ} \mathrm{C}$ until analysis in the interprofessional laboratory. Somatic cell count was determined with a Fossomatic 5000 instrument (A/S N Foss Electric, Hillerød, Denmark), and TBC was analyzed in a Bactoscan 8000 (A/S N Foss Electric). Antibiotic residues in milk were analyzed by the screening test Eclipse 100ov (ZEU-Inmunotec, Zaragoza, Spain), which is a microbial growth inhibition assay containing spores of Bacillus stearothermophilus var. calidolactis C953 and an acid-base indicator. Incubation was done at $65^{\circ} \mathrm{C}$ for $3 \mathrm{~h}$. Positive or negative results were obtained by difference of photometric readings at 590 and $650 \mathrm{~nm}$, in comparison with negative control samples. This technique has been previously validated in raw ewe milk (Berruga et al., 2003) and in ewe and goat milk preserved with acidiol (Montero et al., 2005; Roca et al., 2007; Beltrán et al., 2007). Before and during the analysis period, all equipment was subjected to quality control interlaboratory tests by a reference laboratory (Cecalait, Poligny, France). Residue-positive results were periodically confirmed by microbiological multiplate system or chromatography.

In the CPO recording system, the mean number of repeated records per flock and year were 66 to 68 for the variables studied. The information recorded by the CPO veterinary service included the following variation factors: flock, year and sampling month, milking type (hand and machine milking), monthly milk yield per flock, and antibiotic dry therapy (which was given under veterinary supervision; antibiotic treatments at drying-off were always recorded, so the date and each treated ewe lot were known). When dry therapy was performed, complete dry therapy was always carried out in each ewe lot. The time between dry therapy and lambing was $>2$ mo.

Average herd size was 350 to 400 ewes, which was representative of the Castilla-León region. The reproductive rate in Assaf breed is about 1 lambing/yr. Each 
herd is generally divided into 1 to 3 lots, the lambing periods of which alternate every 12 to 4 mo in the herd. The reproductive features of dairy sheep flocks in the Castilla-León region have been previously defined (Gonzalo et al., 2005).

To study the factors influencing SCC and TBC variations, a mixed model was used in which year $\times$ flock interaction nested within dry therapy group was random and the remaining effects were fixed. The MIXED procedure of SAS (1998) was followed according to the model

$$
\begin{aligned}
& \mathrm{Y}_{\mathrm{ijklmnr}}=\mu+\mathrm{Q}_{\mathrm{i}}+\mathrm{A}_{\mathrm{j}}+\mathrm{QA}_{\mathrm{ij}}+\mathrm{D}_{\mathrm{k}}+\mathrm{QD}_{\mathrm{ik}}+\mathrm{F}_{\mathrm{e}(\mathrm{k})} \\
& +\mathrm{QF}_{\mathrm{ie}(\mathrm{k})}+\mathrm{M}_{\mathrm{m}}+\mathrm{T}_{\mathrm{n}}+\mathrm{QT}_{\mathrm{in}}+\mathrm{bX}_{\mathrm{ijklmnr}}+\mathrm{e}_{\mathrm{ijk} \mathrm{k} m n r},
\end{aligned}
$$

where $\mathrm{Y}_{\mathrm{ijk} k \mathrm{mnr}}$ was the dependent variables $\operatorname{logSCC}$ and $\log \mathrm{TBC} ; \mu$ was the mean; $\mathrm{Q}_{\mathrm{i}}$ was the fixed effect of year; $\mathrm{A}_{\mathrm{j}}$ was the fixed effect of antibiotic residue; $\mathrm{QA}_{\mathrm{ij}}$ was the fixed effect of year $x$ antibiotic residue interaction; $D_{k}$ was the fixed effect of dry therapy group; $\mathrm{QD}_{\mathrm{ik}}$ was the fixed effect of year $\times$ dry therapy group interaction; $F_{e(k)}$ was the fixed effect of flock within dry therapy group; $\mathrm{QF}_{\mathrm{ie}(\mathrm{k})}$ was the random effect of year $\times$ flock interaction nested within dry therapy group; $M_{m}$ was the fixed effect of month; $T_{n}$ was the fixed effect of milking type; $\mathrm{QT}_{\text {in }}$ was the fixed effect of year $\times$ milking type interaction; $\mathrm{X}_{\mathrm{ijk} k m n}$ was the covariable monthly milk yield per flock; b was the slope of regression corresponding to the covariable $\mathrm{X}$; and $\mathrm{e}_{\mathrm{ijk} k \mathrm{mnr}}$ was the random residual effect. The number of observations was 68,781. Five years were considered: 2004 to 2008 . Antibiotic residue factor had 2 levels: negative or positive result. Dry therapy group factor had 3 levels: flocks continuously dry treated throughout the 5 yr of study (complete dry therapy was always performed in all ewes over $5 \mathrm{yr}$ ), flocks never dry treated during the $5 \mathrm{yr}$, and flocks discontinuously dry treated over this time (dry therapy was carried out in only some seasons or years). The number of flocks was 209. The month effect had 12 levels: January to December. Milking type effect was divided into 2 levels: hand and machine milking. Monthly milk yield per flock was calculated throughout each month during the $5 \mathrm{yr}$ studied. The percentage of variance accounted for the model was calculated by dividing the difference between the total variance and the residual variance of the model by the total variance. Estimation of variance components was made considering all model factors as random, using the REML option within the VARCOMP procedure of SAS (SAS Institute, 1998). Percentages of variance explained by each factor were calculated by dividing the corresponding components of variance by the total variance.
A second mathematical model, corresponding to a logistic regression [LOGISTIC procedure of SAS (SAS Institute, 1998)] was made to study the influence of some variables on AR result. The model was

$$
\begin{gathered}
\operatorname{LOGIT}\left(\mathrm{P}_{\mathrm{ijklmnrst}}\right)=\mathrm{b}_{0}+\mathrm{b}_{1} \mathrm{~S}_{\mathrm{i}}+\mathrm{b}_{2} \mathrm{M}_{\mathrm{j}}+\mathrm{b}_{3} \mathrm{M}_{\mathrm{k}}{ }^{2} \\
\begin{aligned}
&+\mathrm{b}_{4} \mathrm{M}_{1}^{3}+ \mathrm{b}_{5} \log \mathrm{SCC}_{\mathrm{m}}+\mathrm{b}_{6} \log \mathrm{TBC}_{\mathrm{n}}+\mathrm{b}_{7} \mathrm{~T}_{\mathrm{r}} \\
&+\mathrm{b}_{8} \mathrm{MILK}_{\mathrm{s}}+\mathrm{e}_{\mathrm{ijklmnrst}},
\end{aligned}
\end{gathered}
$$

where LOGIT $\left(\mathrm{P}_{\mathrm{ijklmnrst}}\right)$ was the lineal logistic model $\ln \left[\mathrm{P}_{\mathrm{ijklmnrst}} /\left(1-\mathrm{P}_{\mathrm{ijklmnrst}}\right)\right], \mathrm{P}_{\mathrm{ijklmnrst}}$ being the probability of positive response of an observation and $\left(1-\mathrm{P}_{\mathrm{ijklmnrst}}\right)$ being the probability of a negative result; $b_{0}$ to $b_{8}$ were coefficients estimated for the logistic regression model; $\mathrm{S}_{\mathrm{i}}$ was the effect of semester (10 levels corresponding to 10 semesters over $5 \mathrm{yr}) ; \mathrm{M}_{\mathrm{j}}$ was the effect of month (12 levels corresponding to 12 months); $\mathrm{M}_{\mathrm{k}}{ }^{2}$ was the effect of month squared; $\mathrm{M}_{1}^{3}$ was the effect of month cubed; $\mathrm{T}_{\mathrm{r}}$ was the effect of antibiotic dry therapy, in dummy variable, with $\mathrm{Z}=0$ and $\mathrm{Z}=1$ for bulk tank samples belonging to flocks with or without dry therapy, respectively, during the previous drying-off; MILK $_{\mathrm{s}}$ was the flock monthly milk yield; and $\mathrm{e}_{\mathrm{ijk} k \mathrm{mnrst}}$ was the residual error. The number of observations considered in this analysis was 68,781 . The concordance coefficient was applied as a rank correlation between the observed responses and predicted probabilities. This model was partially based on the regression model for the antibiotic residue used by Molina et al. (2003) and Yamaki et al. (2004).

A third model was used to analyze the variation factors of AR according to a categorical model using the CATMOD procedure of SAS (1998). This model was

$$
\mathrm{Y} \cong \mathrm{Q}+\mathrm{D}+\mathrm{QD}+\mathrm{T}+\mathrm{M},
$$

where $\mathrm{Y}$ was the antibiotic residue occurrence; Q was the effect of year ( 5 levels); D was the effect of dry therapy group (with the same 3 levels as in the mixed model); QD was year $\times$ dry therapy group interaction, although it was not statistically significant; $T$ was the effect of milking type (2 levels: hand and machine milking); and $\mathrm{M}$ was the effect of month (12 levels). The record number considered in this analysis was 71,228 belonging to 209 flocks.

A variant of this categorical model was carried out including the effect semester (10 levels), dry therapy (2 levels: with or without dry therapy during the previous drying-off) and milking type (2 levels). This last model did not include the month factor. The objective of this variant was to study 1) the variations of $\mathrm{AR}$ result by semester instead of year and 2) dry therapy 
effect instead of dry therapy group. The AR differences were tested for the statistically significant factors by a chi-square analysis using the FREQ procedure of SAS (1998).

\section{RESULTS AND DISCUSSION}

Global AR occurrence in ewe milk for all of the studied period was $0.60 \%$. This occurrence was similar to results observed in cow milk in other European Union countries (0.3-1.4\%; Surhen and Walte, 2003), higher than occurrences found in cow milk from the United States (0.03-0.4\%; Ruegg and Tabone, 2000; van Schaik et al., 2002), and lower than values reported in the Manchega ewe flocks in the Castilla-La Mancha region (1.7\%; Yamaki et al., 2004). Means of logSCC and $\log$ TBC were $5.94 \pm 0.001$ (geometric mean: $879 \times$ $10^{3}$ cells $/ \mathrm{mL}$ ) and $5.14 \pm 0.002$ (geometric mean: 138 $\times 10^{3} \mathrm{cfu} / \mathrm{mL}$ ), respectively. These values were similar to those reported for ewe dairy flocks in the same geographical area (Gonzalo et al., 2005, 2006), although higher than those obtained in dairy cattle (Jayarao et al., 2004). A large SCC response to IMI along with lower individual milk yields and the absence of teatwashing practice before milking might partially explain higher SCC and TBC in dairy sheep compared with dairy cattle.

Logistic regression showed important effects of SCC, antibiotic dry therapy, semester, month, and milk yield on AR result in ewe flocks (Table 1) with high chi-square values $(13.7-100.1 ; P<0.001)$. The TBC factor had less influence on AR result; it showed a low chi-square value $(6.0 ; P<0.05)$. The concordance correlation coefficient of the model was 0.69 .

High bulk tank milk SCC were associated with increased AR violations. Results from the mixed-model ANOVA of factors affecting SCC evidenced greater SCC

Table 1. Estimation of the coefficients of the logistic regression model for the antibiotic residue, and statistical significance ${ }^{1}$

\begin{tabular}{lccc}
\hline Parameter & df & Estimate $\left(\times 10^{4}\right)$ & Chi-square \\
\hline Intercept & 1 & $-184,697$ & $129.22^{* * *}$ \\
Semester & 1 & $-1,534$ & $49.59^{* * *}$ \\
Month-linear & 1 & $-7,743$ & $13.70^{* * *}$ \\
Month-quadratic & 1 & 1,490 & $16.88^{* * *}$ \\
Month-cubic & 1 & -74.3 & $16.90^{* * *}$ \\
LogSCC & 1 & 19,369 & $62.21^{* * *}$ \\
LogTBC & 1 & 2,785 & $6.03^{*}$ \\
Dry therapy & 1 & 13,653 & $100.10^{* * *}$ \\
Milk yield & 1 & -0.49 & $17.26^{* * *}$ \\
\hline
\end{tabular}

${ }^{1}$ Concordance correlation coefficient: 0.69 ; number of observations: 68,781 .

${ }^{2}$ TBC: total bacterial count.

${ }^{*} P<0.05 ;{ }^{* * *} P<0.001$.
$(P<0.001)$ in the case of AR presence compared with its absence (logSCC: 6.01 and geometric mean: 1,018 $\times 10^{3}$ cells $/ \mathrm{mL}$ vs. $\operatorname{logSCC}: 5.94$ and geometric mean: $879 \times 10^{3}$ cells $/ \mathrm{mL}$ ), which is in accordance with other studies in dairy cattle (Sargeant et al., 1998; Ruegg and Tabone, 2000; van Schaik et al., 2002). High SCC values indicate that the flock has a high prevalence of subclinical mastitis and it is reasonable to expect a greater frequency of IMI antibiotic treatments. Thus, programs to reduce the level of subclinical mastitis in dairy ewe flocks may have an additional benefit of reducing the $\mathrm{AR}$ violations.

Frequencies of AR occurrence and the statistical signification of dry therapy, month, and semester effects were analyzed by logistic regression and CATMOD procedures. All above-mentioned effects contributed significantly to AR variation. Dry therapy was a very important variation factor of AR occurrence; when dry therapy was implemented, AR occurrence $(0.78 \%)$ was higher $(P<0.001)$ than when this practice was not used $(0.36 \%)$. An increased frequency of use of lactating and dry IMI antibiotics has been also related to the AR violations in dairy cows (Allison, 1985; Mitchell et al., 1998). In the case of dairy sheep, AR occurrence would increase after dry therapy because of mismanagement of dry treated ewes (e.g., some ewes are not separated from the milking lot after dry therapy) and also in the lambing season if the postpartum withdrawal period is not enforced in any animal.

Figure 1 shows AR occurrence distribution according to the month. Results indicated an important peak of maximal occurrences in autumn, particularly in October (1.14\%), and minimal percentages in spring, particularly in June $(0.28 \%)$; the differences between maximum and minimum values were statistically significant. In the logistic regression, this evolution corresponded to a third grade polynomial distribution. The monthly occurrence of AR was inversely related $(P<0.001)$ with the monthly distribution of milk yield (Table 1; Figure 1). The highest AR occurrences in autumn were associated with the lowest milk yields and, consequently, with the highest frequency of antibiotic dry treatments in the ewes, as well as with the beginning of the autumn lambing period. On the contrary, very low AR occurrence values during the spring were associated with large volumes of milk and a lower frequency of dry therapy practice. Yamaki et al. (2004) reported a similar effect of month in Manchega ewes in the Castilla-La Mancha region, with the highest percentages of AR-positive results in late summer-early autumn. These authors related AR occurrence to TBC increases, but information about dry therapy or other management factors influencing $\mathrm{AR}$ variation is lacking in this study. 


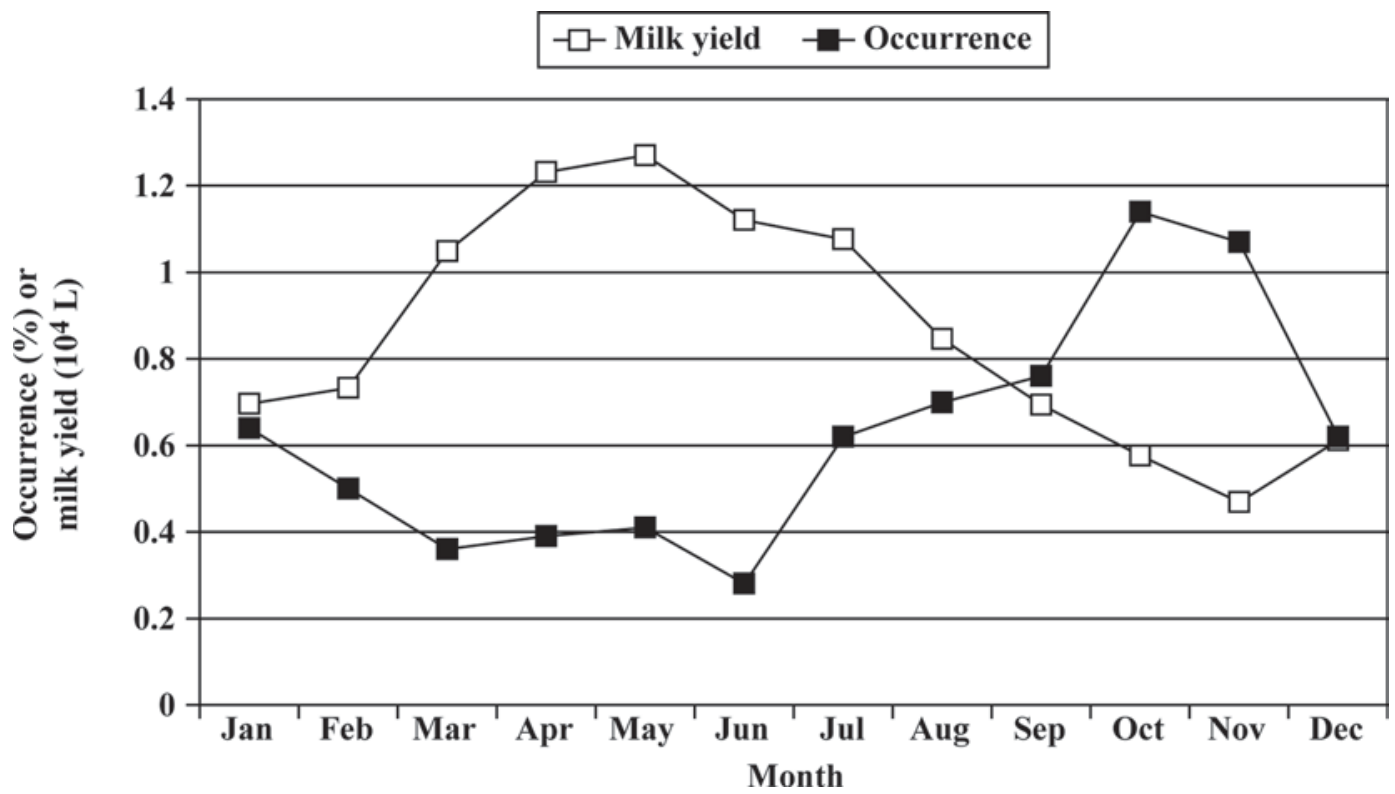

Figure 1. Monthly evolution of antibiotic residue occurrence $(\%)$ and milk yield $\left(\times 10^{4} \mathrm{~L}\right)$ per flock (SEM of monthly milk yield/flock: $\left.0.0145 \times 10^{4}\right)$.

The above-mentioned distribution over the year explained a very important effect of the semester; the first semester $(0.43 \%)$ evidenced lower AR occurrence $(P<0.001)$ than the second semester $(0.80 \%)$. Figure 2 shows AR biannual frequencies throughout 5 yr involved in this study. The AR violations were always higher in the second semester than in the first semester for all years. At the same time, a progressive decrease $(P<0.001)$ of AR violations was observed over time; the yearly occurrences drastically diminished from $2004(1.36 \%)$ to 2008 (0.30\%; Table 2$)$. These results were compatible with a very significant diminution of producers with reported histories of $\mathrm{AR}$ violations in 2 consecutive years in the present study $(11.00 \%$ in $2004-2005$ to $5.26 \%$ in 2007-2008), probably because testing and audit programs, combined with incentive and educational resources, have been implemented in the last $5 \mathrm{yr}$ in the CPO flocks to increase ewe milk safety (Gonzalo et al., 2004a, 2009). Briefly, a risk assessment was carried out in situ in each flock by CPO veterinarians after each antibiotic violation. This tool was similar to that implemented by Sischo et al. (1997) in dairy cattle based on the Milk and Dairy Beef Quality Assurance Program. The objective was to modify the risk perception of dairy sheep producers; however, this methodology has been updated and risk weight of Hazard Analysis Critical Control Points (HACCP) has been changed throughout the time, so results are not shown in this study. In addition, all dairy flocks were audited yearly and specific educational programs were implemented for producers with AR violations, and particularly for producers with reported histories of AR occurrence.

Somatic cell count and TBC variations were analyzed by a mixed model that explained 74.1 and $35.4 \%$ of total variance, respectively; thus, the mathematical model used was especially suitable to study SCC variable. Considering the percentages of variance explained by each factor (Table 3), the quantitative most important effects influencing SCC and TBC variations were flock, dry therapy group, year $\times$ flock interaction, and milking type. The effects of year, month, and year $x$ dry therapy group interaction were also important $(P$ $<0.001$ ) within the context of the present study. The presence of antibiotic residues in milk and the year $x$ milking type interaction were only significant for SCC; year $\times$ antibiotic residue interaction was not significant for any variable.

Flock accounted for 21.8 and $12.5 \%$ of total variation in SCC and TBC, respectively, and was, therefore, a very significant source of variation for both variables (Table 3). Thus, differences in management and hygiene practice in flocks would cause relevant SCC and TBC variations among flocks. Year $\times$ flock interaction explained 13.8 and $7.1 \%$ of total variance for SCC and TBC variables, respectively, and was also a very important $(P<0.001)$ source of variation (Table 3$)$. This indicated that flocks showed significant variations in SCC and TBC throughout the $5 \mathrm{yr}$ of the study, which could be explained by yearly differences in management 
Table 2. Antibiotic residue (AR) occurrence, affected by year

\begin{tabular}{lccccc}
\hline Variable & 2004 & 2005 & 2006 & 2007 & 2008 \\
\hline AR occurrence (\%) & $1.36^{\mathrm{a}}$ & $0.63^{\mathrm{b}}$ & $0.69^{\mathrm{b}}$ & $0.42^{\mathrm{c}}$ & $0.30^{\mathrm{d}}$ \\
Observations (n) & 8,190 & 14,741 & 15,944 & 14,305 & 18,048 \\
\hline
\end{tabular}

${ }^{\mathrm{a}-\mathrm{d}}$ Means within a row with different superscripts differ $(P<0.05)$.

practices and hygienic conditions within flocks. In this sense, hygiene varies not only among flocks but also within flock over time.

The variation throughout $5 \mathrm{yr}$ of SCC and TBC allowed the analysis of the effect of dry therapy group, which has not yet been investigated in dairy sheep. As shown in Table 4, the lowest SCC (logSCC: 5.80 and geometric mean: $631 \times 10^{3}$ cells $/ \mathrm{mL}$ ) and TBC (logTBC: 4.92 and geometric mean: $83 \times 10^{3} \mathrm{cfu} / \mathrm{mL}$ ) values were found in flocks in which dry therapy was always applied, and the highest SCC (logSCC: 6.10 and geometric mean: $1,259 \times 10^{3}$ cells $/ \mathrm{mL}$ ) and TBC (logTBC: 5.18 and geometric mean: $151 \times 10^{3} \mathrm{cfu} / \mathrm{mL}$ ) values were found for flocks in which dry therapy was never carried out. Those flocks in which dry therapy was not continuously practiced had SCC (logSCC: 6.01 and geometric mean: $1,023 \times 10^{3}$ cells $/ \mathrm{mL}$ ) and TBC (logTBC: 5.05 and geometric mean: $112 \times 10^{3} \mathrm{cfu} / \mathrm{mL}$ ) values ranging between those of the 2 other groups (Table 4). These results showed that dry therapy was generally associated with improved milking hygiene in subsequent lactation, so this practice, particularly when is continuously applied, is an efficient method of reducing SCC and TBC and improving the hygiene and health quality of milk. In addition, in the analysis of AR occurrences by categorical model, important differences in occurrences $(P<0.001)$ were obtained among 3 dry therapy groups (Table 4 ). Discontinuously dry treated flocks $(0.71 \%)$ had higher occurrences $(P$
$<0.05)$ than continuously dry treated flocks $(0.57 \%)$. The main reasons for inconstant dry therapy applications were unsatisfactory results, labor variation, and educational background. The smallest AR occurrence was observed for flocks in which dry therapy was never performed $(0.38 \%)$; the origin of these residues were probably the treatments in lactation associated with high SCC (clinical mastitis) and occasionally other treatments (e.g., for metritis in postpartum period, pneunomia, and lameness). The presence of AR in milk indicated that withdrawal periods were not respected. In dairy sheep, antibiotic treatments in case of subclinical mastitis are not performed in lactating animals but rather in the beginning of drying-off. As a whole, these results indicated that continuous dry therapy over time is a more advisable practice to reduce SCC, TBC, and AR occurrence in dairy ewe flocks compared with discontinuous dry therapy.

Table 5 and Figure 3 show the year effect on each variable and the year $\times$ dry therapy group interaction, respectively. Somatic cell count progressively increased $(P<0.001)$ from 2004 (logSCC: 6.04 and geometric mean: $1,096 \times 10^{3}$ cells $/ \mathrm{mL}$ ) to 2008 (logSCC: 6.18 and geometric mean: $1,514 \times 10^{3}$ cells $/ \mathrm{mL}$ ) in the untreated group; geometric mean increased $38.1 \%$ throughout time when dry therapy was never practiced. This yearly evolution indicated a progressive increase of IMI prevalence in untreated flocks. The variations were smaller in the dry treated groups: in discontinuously dry treated

Table 3. Test of significance for factors affecting bulk tank SCC and total bacterial count (TBC) based on a mixed model analysis, and variance explained (VE) by each factor

\begin{tabular}{|c|c|c|c|c|c|}
\hline \multirow[b]{2}{*}{ Factor } & \multirow[b]{2}{*}{$\mathrm{df}$} & \multicolumn{2}{|c|}{$\operatorname{LogSCC}$} & \multicolumn{2}{|c|}{$\operatorname{LogTBC}$} \\
\hline & & $F$ & $\mathrm{VE}(\%)$ & $F$ & $\mathrm{VE}(\%)$ \\
\hline Month & 11 & $412.19^{* * *}$ & 1.91 & $85.32 * * *$ & 1.14 \\
\hline Year & 4 & $7.26^{* * *}$ & 1.32 & $5.57^{* * *}$ & 1.63 \\
\hline Antibiotic residues & 1 & $34.91^{* * *}$ & 1.10 & $1.76^{\mathrm{NS}}$ & 0.02 \\
\hline Dry therapy group & 2 & $499.03^{* * *}$ & 21.27 & $113.25^{* * *}$ & 3.86 \\
\hline Milking type & 1 & $33.31^{* * *}$ & 10.90 & $36.28^{* * *}$ & 7.37 \\
\hline Flock (dry therapy group) & 206 & $8.39^{* * *}$ & 21.85 & $8.23^{* * *}$ & 12.48 \\
\hline Year $\times$ antibiotic residues & 4 & $1.50^{\mathrm{NS}}$ & 0.08 & $1.63^{\mathrm{NS}}$ & 0.38 \\
\hline Year $\times$ dry therapy group & 8 & $5.45^{* * *}$ & 1.12 & $5.32^{* * *}$ & 0.73 \\
\hline Year $\times$ milking type & 4 & $3.53^{* *}$ & 0.71 & $2.13^{\mathrm{NS}}$ & 0.64 \\
\hline Year $\times$ flock (dry therapy group) ${ }^{1}$ & - & - & 13.85 & - & 7.12 \\
\hline Total & 68,780 & & & & \\
\hline
\end{tabular}

${ }^{1}$ Random factor absorbed in the mixed model.

${ }^{* *} P<0.01 ;{ }^{* * *} P<0.001$. 


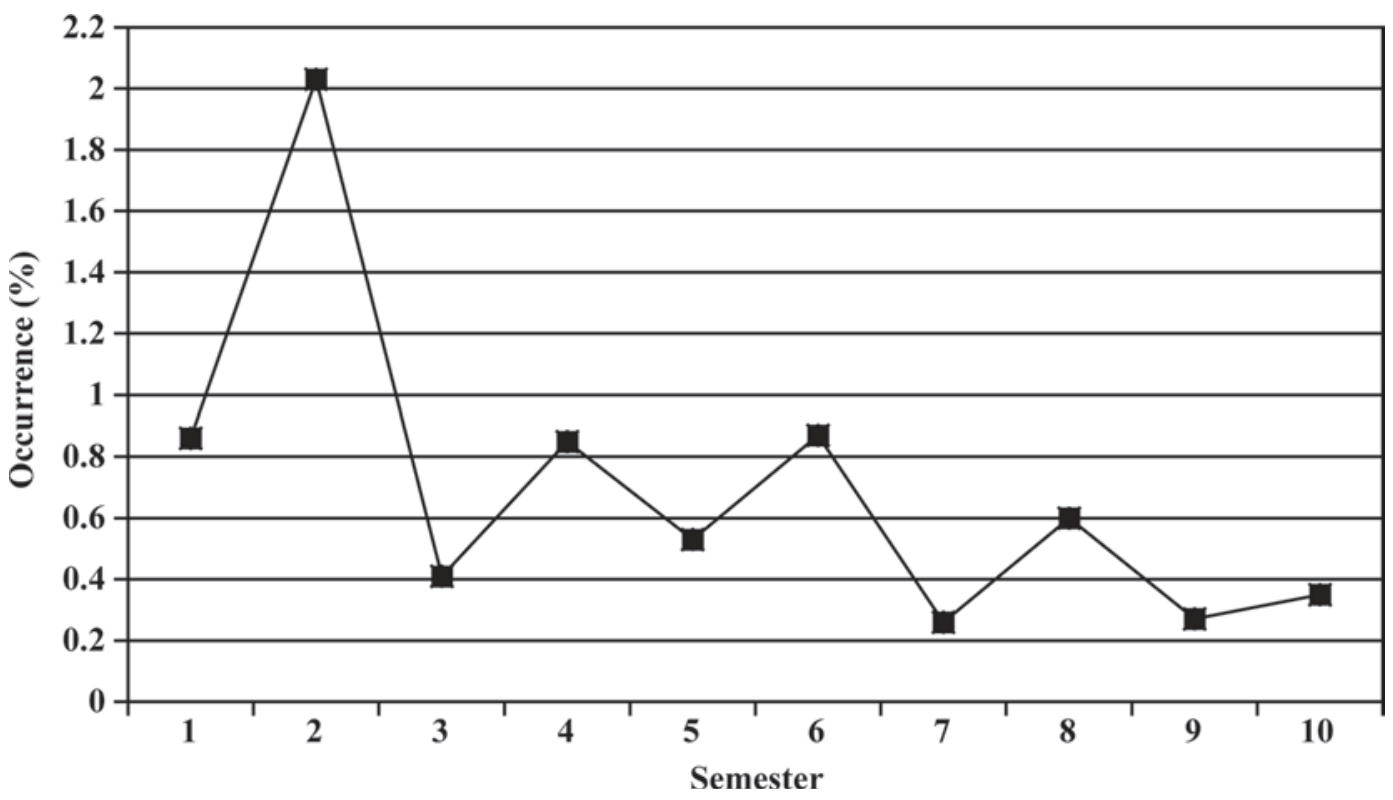

Figure 2. Half-yearly evolution of antibiotic residue occurrence (\%) throughout the 5-yr study.

flocks, SCC values decreased $(P<0.05)$ in 2005 , were similar $(P>0.05)$ from 2005 to 2007 , and increased $(P$ $<0.05)$ in 2008, whereas for continuously dry treated flocks, SCC values in 2004, 2006, and 2008 were higher $(P<0.05)$ than values in 2005 and 2007 (Figure 3). These yearly variations in dry treated groups are not easy to predict, although they could be considered normal. For all 3 groups studied (Table 5), the evolution throughout 5 yr study evidenced lowest SCC values for 2005 (logSCC: 5.94 and geometric mean: $870 \times 10^{3}$ cells $/ \mathrm{mL}$ ) and highest values for 2008 (logSCC: 6.04 and geometric mean: $1,096 \times 10^{3}$ cells $\left./ \mathrm{mL}\right)$. On the other hand, for TBC variable, important decreases $(P<$ $0.001)$ were evidenced in the last $2 \mathrm{yr}$ in the dry treated groups, but not $(P>0.05)$ in untreated flocks (Figure
3). As a whole (Table 5), lower TBC corresponded to 2007 and 2008 ( $\log$ TBC: 4.96 and geometric mean: 91 $\left.\times 10^{3} \mathrm{cfu} / \mathrm{mL}\right)$.

Month was also a significant source of variation, but the variance accounted for this effect was low (1.9 and $1.1 \%$ for SCC and TBC, respectively). For SCC, maximal values were observed for July (logSCC: 6.01 and geometric mean: $1,023 \times 10^{3}$ cells $/ \mathrm{mL}$ ), August (logSCC: 6.03 and geometric mean: 1,061 $\times 10^{3}$ cells $/ \mathrm{mL}$ ), and September (logSCC: 6.02 and geometric mean: $1.044 \times 10^{3}$ cells $/ \mathrm{mL}$ ), coinciding with decreasing milk yields (Figure 1). For TBC, maximal values were found in October (logTBC: 5.14 and geometric mean: $138 \times$ $10^{3}$ cells $/ \mathrm{mL}$ ), November (logTBC: 5.15 and geometric mean: $140 \times 10^{3}$ cells $\left./ \mathrm{mL}\right)$, December $(\log$ TBC: 5.09

Table 4. Least squares means, standard errors, and geometric means of SCC and total bacterial count (TBC) bulk tank milk variables affected by dry therapy group, including the antibiotic residue (AR) occurrences in each group

\begin{tabular}{lccc}
\hline Variable & Untreated flocks & $\begin{array}{c}\text { Discontinuously } \\
\text { dry treated flocks }\end{array}$ & $\begin{array}{c}\text { Continuously dry } \\
\text { treated flocks }\end{array}$ \\
\hline LogSCC & $6.10^{\mathrm{a}}$ & $6.01^{\mathrm{b}}$ & $5.80^{\mathrm{c}}$ \\
SE of logSCC & 0.01 & 0.01 & 0.01 \\
SCC & 1,259 & 1.023 & 631 \\
LogTBC & $5.18^{\mathrm{a}}$ & $5.05^{\mathrm{b}}$ & $4.92^{\mathrm{c}}$ \\
SE of $\operatorname{logTBC}$ & 0.02 & 0.02 & 0.02 \\
TBC & 151 & 112 & 83 \\
Observations for SCC and TBC variables (n) & 13,351 & 33,733 & 21,697 \\
AR occurrence (\%) & $0.38^{\mathrm{a}}$ & $0.71^{\mathrm{b}}$ & $0.57^{\mathrm{c}}$ \\
Observations for AR result (n) & 13,811 & 34,980 & 22,437 \\
\hline
\end{tabular}

${ }^{\mathrm{a}-\mathrm{c}}$ Means within a row with different superscripts differ $(P<0.05)$.

${ }^{1}$ Geometric mean $\left(\times 10^{3}\right.$ cells $\left./ \mathrm{mL}\right)$.

${ }^{2}$ Geometric mean $\left(\times 10^{3} \mathrm{cfu} / \mathrm{mL}\right)$. 
Table 5. Least squares means, standard errors, and geometric means of SCC and total bacterial count (TBC) variables of bulk tank milk affected by year

\begin{tabular}{lccccc}
\hline Variable & 2004 & 2005 & 2006 & 2007 & 2008 \\
\hline LogSCC & $5.96^{\mathrm{ab}}$ & $5.94^{\mathrm{a}}$ & $5.96^{\mathrm{ab}}$ & $5.98^{\mathrm{b}}$ & $6.04^{\mathrm{c}}$ \\
SE of $\operatorname{logSCC}$ & 0.01 & 0.01 & 0.01 & 0.02 & 0.02 \\
SCC $^{1}$ & 901 & 860 & 906 & 947 & 1,091 \\
LogTBC $_{\text {SE of } \operatorname{logTBC}}$ & $5.07^{\mathrm{a}}$ & $5.14^{\mathrm{a}}$ & $5.13^{\mathrm{a}}$ & $4.96^{\mathrm{b}}$ & $4.96^{\mathrm{b}}$ \\
TBC $^{2}$ & 0.03 & 0.03 & 0.03 & 0.04 & 0.04 \\
Observations for SCC and TBC variables (n) & 7,742 & 137 & 135 & 92 & 90 \\
\hline
\end{tabular}

${ }^{\mathrm{a}-\mathrm{c}}$ Means within a row with different superscripts differ $(P<0.05)$.

${ }^{1}$ Geometric mean $\left(\times 10^{3}\right.$ cells $\left./ \mathrm{mL}\right)$.

${ }^{2}$ Geometric mean $\left(\times 10^{3} \mathrm{cfu} / \mathrm{mL}\right)$.

and geometric mean: $123 \times 10^{3}$ cells $/ \mathrm{mL}$ ), and January (logTBC: 5.06 and geometric mean: $114 \times 10^{3}$ cells/ $\mathrm{mL}$ ), coinciding with low milk yields, a rainy climate, and confinement. For milking type (Table 3), machine milking (logSCC: 5.92 and geometric mean: $832 \times 10^{3}$ cells $/ \mathrm{mL})$ elicited a lower $(P<0.001)$ SCC than hand milking (logSCC: 6.25 and geometric mean: $1,774 \times$ $10^{3}$ cells $\left./ \mathrm{mL}\right)$; similarly, machine milking showed lower $(P<0.001)$ TBC (logTBC: 4.98 and geometric mean: $96 \times 10^{3} \mathrm{cfu} / \mathrm{mL}$ ) than hand milking (logTBC: 5.28 and geometric mean: $\left.191 \times 10^{3} \mathrm{cfu} / \mathrm{mL}\right)$. These results agree with those obtained in previous observational studies (Gonzalo et al., 2005, 2006) and reflect the inferior hygiene conditions of hand milking compared with machine milking. Year $\times$ milking type interaction was significant only for SCC, the percentage of variance explained by this factor being very low $(0.71 \%)$, as shown in Table 3 .

\section{CONCLUSIONS}

Milk quality data from a large population of ewe dairy flocks in the Castilla-León region indicate that AR occurrence and SCC and TBC bulk tank milk variables can be used for monitoring mammary health, milk hygiene, and safety in dairy sheep over time. High SCC were associated with increased AR violations. A monthly polynomial distribution of AR occurrence throughout the year was evidenced and inversely related to milk yield, the highest AR occurrences being in

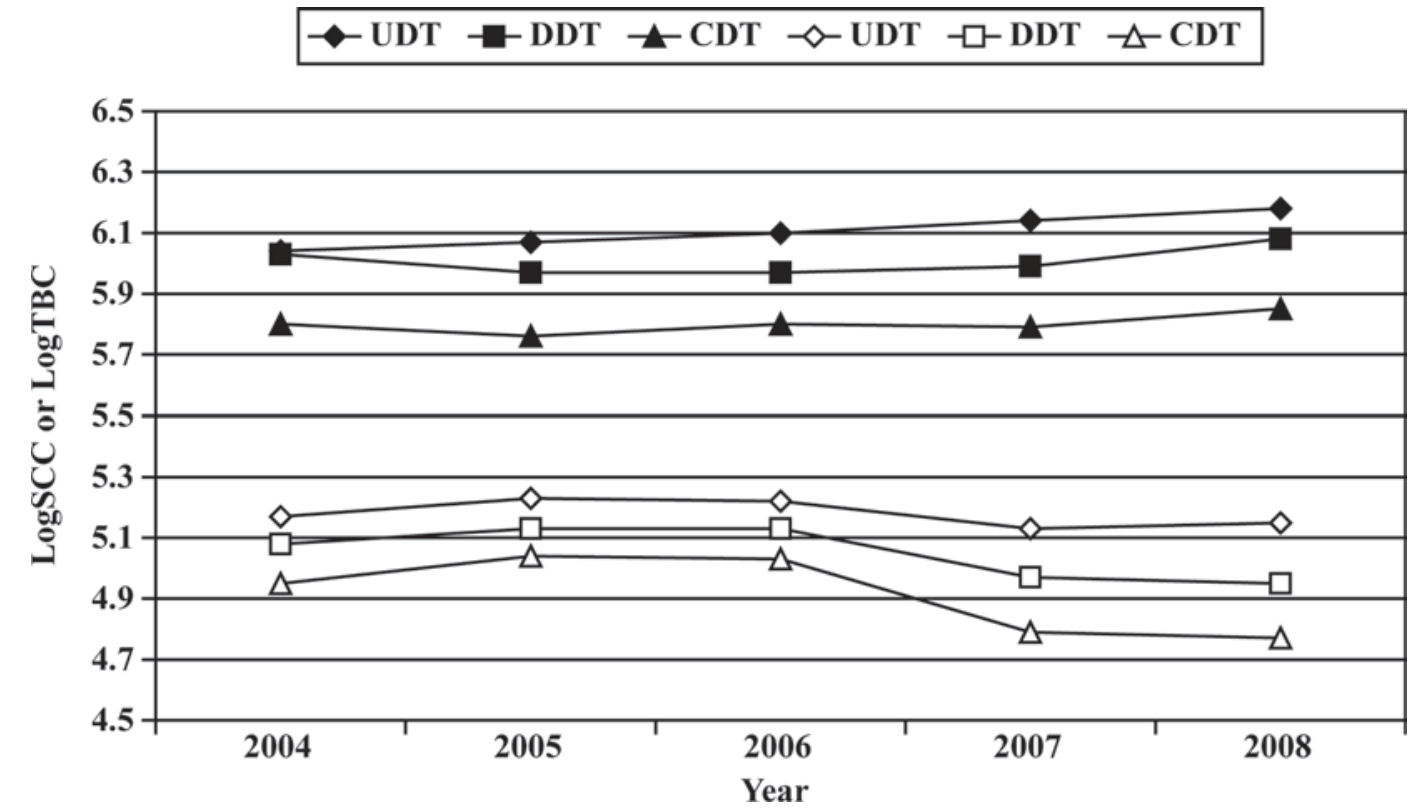

Figure 3. Yearly evolution of logarithm values of bulk tank milk variables SCC (black points) and total bacterial count (TBC; white points) by dry therapy group: continuous dry treated (CDT), discontinuous dry treated (DDT), and untreated (UDT; SEM of logSCC and logTBC: 0.02 and 0.03 , respectively). 
autumn. Measurable improvements in AR occurrence found throughout $5 \mathrm{yr}$ of the study would be associated with incentive, education, and training programs implemented to increase milk safety in CPO flocks. The 2 main target groups of dairy flocks to improve milk quality were untreated or discontinuously dry treated flocks. Affecting these 2 groups would result in a significant improvement of milk quality. Indeed, mastitis control programs based on continuous dry therapy significantly reduced SCC and TBC and showed lower AR occurrences than mastitis programs based on discontinuous dry therapy. In addition, TBC increases in autumn-early winter were related to low milk yields and a rainy climate.

\section{ACKNOWLEDGMENTS}

This paper was developed within the project AGL2008-00422/GAN, supported by Ministerio de Ciencia e Innovación (Madrid, Spain), and within the agreement between the Universidad de León (León, Spain) and the Consorcio de Promoción del Ovino, (Villalpando, Zamora, Spain).

\section{REFERENCES}

Allison, J. R. D. 1985. Antibiotic residues in milk. Br. Vet. J. 141:121-124.

Beltrán, M. C., R. L. Althaus, I. Berruga, A. Molina, and M. P. Molina. 2007. Microbiological methods for the detection of inhibitors in goat milk. Pages 147-149 in 5th Int. Symp. Challenge to Sheep and Goats Milk Sectors, IDF Special Issue 0801/Part 2, Alghero, Italy. International Dairy Federation, Brussels, Belgium.

Berruga, M. I., M. Yamaki, R. L. Althaus, M. P. Molina, and A. Molina. 2003. Performances of antibiotic screening tests in determining the persistence of penicillin residues in ewe's milk. J. Food Prot. 66:2097-2102.

European Union. 1990. Council Regulation (EEC) No. 2377/90 of 26 June 1990 laying down a Community procedure for the establishment of maximum residue limits of veterinary medical products in foodstuffs of animal origin. Off. J. L 224:1-8.

European Union. 2004. Council Regulation (EC) No. 853/2004 of 29 April 2004 laying down specific hygiene rules for food of animal origin. Off. J. L 226:22-82.

Gonzalo, C., A. Ariznabarreta, J. A. Carriedo, and F. San Primitivo. 2002. Mammary pathogens and their relationship to somatic cell count and milk yield losses in dairy ewes. J. Dairy Sci. 85:14601467.

Gonzalo, C., J. A. Asensio, M. A. Blanco, J. Calvo, M. C. García, M. Pérez, and M. L. de Garnica. 2009. Évaluation de la sécurité alimentaire en ferme et relation avec la qualité hygiénique du lait de tank dans les troupeaux ovins laitiers. 16e Journées 3R. INRAInstitut de l'Elevage, Paris, France.

Gonzalo, C., M. A. Blanco, C. Palacios, A. Martínez, E. Beneitez, F. González, M. T. Juárez, and J. C. Granado. 2004a. Buenas
Prácticas Ganaderas, Control de Riesgos y Sistemas Integrales de Calidad y Seguridad Alimentaria en las Explotaciones de Ganado Ovino y Caprino. Consorcio de Promoción del Ovino, Villalpando, Zamora, Spain

Gonzalo, C., J. A. Carriedo, E. Beneitez, M. T. Juárez, F. De La Fuente, and F. San Primitivo. 2006. Bulk tank total bacterial count in dairy sheep: Factors of variation and relationship with somatic cell count. J. Dairy Sci. 89:549-552.

Gonzalo, C., J. A. Carriedo, M. A. Blanco, E. Beneitez, M. T. Juárez, F. De La Fuente, and F. San Primitivo. 2005. Factors of variation influencing bulk tank somatic cell count in dairy sheep. J. Dairy Sci. 88:969-974.

Gonzalo, C., J. A. Tardáguila, L. F. De La Fuente, and F. San Primitivo. 2004b. Effects of selective and complete dry therapy on prevalence of intramammary infection and on milk yield in the subsequent lactation in dairy ewes. J. Dairy Res. 71:33-38.

Jayarao, B. M., S. R. Pillai, A. A. Sawant, D. R. Wolfgang, and N. V. Hegde. 2004. Guidelines for monitoring bulk tank milk somatic cell and bacterial counts. J. Dairy Sci. 87:3561-3573.

Marco, J. C. 1994. Mastitis en la oveja Latxa: Epidemiología, diagnóstico y control. PhD Thesis. Univ. Zaragoza, Spain.

Mitchell, J. M., M. W. Griffiths, S. A. McEwen, W. B. McNab, and A. J. Yee. 1998. Antimicrobial drug residues in milk and meat: Causes, concerns, prevalence, regulations, tests, and test performance. J. Food Prot. 61:742-756.

Molina, M. P., R. L. Althaus, S. Balasch, A. Torres, C. Peris, and N. Fernández. 2003. Evaluation of screening test for detection of antimicrobial residues in ewe milk. J. Dairy Sci. 86:1947-1952.

Montero, A., R. L. Althaus, A. Molina, I. Berruga, and M. P. Molina. 2005. Detection of antimicrobial agents by a specific microbiological method (Eclipse 100) for ewe milk. Small Rumin. Res. 57:229237

Raynal-Ljutovac, K., A. Pirisi, R. de Crémoux, and C. Gonzalo. 2007. Somatic cells and goat and sheep milk: Analytical, sanitary, productive and technological aspects. Small Rumin. Res. 68:126144

Roca, M. I., I. Berruga, A. Molina, R.L. Althaus, and M. P. Molina. 2007. Influencia de factores metodológicos sobre los métodos microbiológicos de detección de inhibidores en leche de oveja. Pages 89-92 in Proc. XXXII Jornadas Científicas y XI Jornadas Internacionales de la Sociedad Española de Ovinotecnia y Caprinotecnia. S.E.O.C., Mallorca, Spain.

Ruegg, P. L., and T. J. Tabone. 2000. The relationship between antibiotic residues violations and somatic cell counts in Wisconsin dairy herds. J. Dairy Sci. 83:2805-2809.

Sargeant, J. M., Y. H. Schukken, and K. E. Leslie. 1998. Ontario bulk milk somatic cell count reduction program: Progress and outlook. J. Dairy Sci. 81:1545-1554.

SAS Institute. 1998. SAS User's Guide: Statistics. Release 6.12. SAS Inst. Inc., Cary, NC.

Sischo, W. M., N. E. Kiernan, C. M. Burns, and L. I. Byler. 1997. Implementing a quality assurance program using a risk assessment tool on dairy operations. J. Dairy Sci. 80:777-787.

Surhen, G., and H. G. Walte. 2003. Experiences with the application of method combinations for the detection of residues of antimicrobial drugs in milk from collecting tankers. Milchwissenschaft 58:536540.

van Schaik, G., M. Lotem, and Y. H. Schukken. 2002. Trends in somatic cell counts, bacterial counts, and antibiotic residue violations in New York State during 1999-2000. J. Dairy Sci. 85:782-789.

Yamaki, M., M. I. Berruga, R. L. Althaus, M. P. Molina, and A. Molina. 2004. Occurrence of antibiotic residues in milk from Manchega ewe dairy farms. J. Dairy Sci. 87:3132-3137. 